\title{
Cytogenetical Studies of Accessory Chromosomes in the Genus Cymbopogon Spreng
}

\author{
Vijeshwar Verma and S.N. Sobti \\ Regional Research Laboratory, Canal Road, Jammu-180001, India
}

Accepted March 27, 1984

Cymbopogon, an important genus of aromatic grasses, consists of nearly 140 species (Verma 1981) of these only a few have been studied cytologically. In India the genus is represented by about 22 species, many of which are cultivated (Jagadish Chandra 1975a, b).

The genus is monobasic with $\mathrm{x}=10$ and $\mathrm{B}$-chromosomes have been reported in 7 out of 22 Indian species (Verma 1981). In the present study supernumerary chromosomes were detected in two species, C. martinii var. motia $(2 \mathrm{n}=20)$ and C. jwarancusa $(2 \mathrm{n}=20)$ out of the 9 species investigated. No B-chromosomes were detected in the polyploid species. The B-chromosomes were found both in the root-tip meristematic cells as well as the PMCs. The present paper deals with the nature and behaviour of these supernumerary chromosomes in the above two species, their $F_{1}$ hybrids with other Cymbopogon species and in the $F_{2}$ population raised from one of the partially fertile $F_{1}$ hybrid.

\section{Material and methods}

The plants were collected from their wild habitat during routine collection and grown in the experimental garden of the laboratory. C. jwarancusa was collected from Nanital while C. martinii var. motia plants were collected from Haldwani. Herbarium sheets of these plants are deposited in the herbarium of the Regional Research Laboratory, Jammu.

Root-tip and male meiosis squashes were made by the standard methods using aceto-orcein and aceto-carmine stains, respectively. Observations and photomicrographs were taken from the temporary preparations which were later made permanent. For denoting the position of centromere in the chromosomes the terminology adopted is reported earlier (Verma and Sobti 1982).

\section{Results}

Following types of studies were made:

1. Study of B-chromosomes in two parental species

The two parental species $C$. martinii var. motia and $C$. jwarancusa were taken up for the present study after screening 9 species and varieties for the presence of B-chromosomes.

In C. martinii var. motia $(2 \mathrm{n}=20)$ the frequency of B-chromosomes ranged 


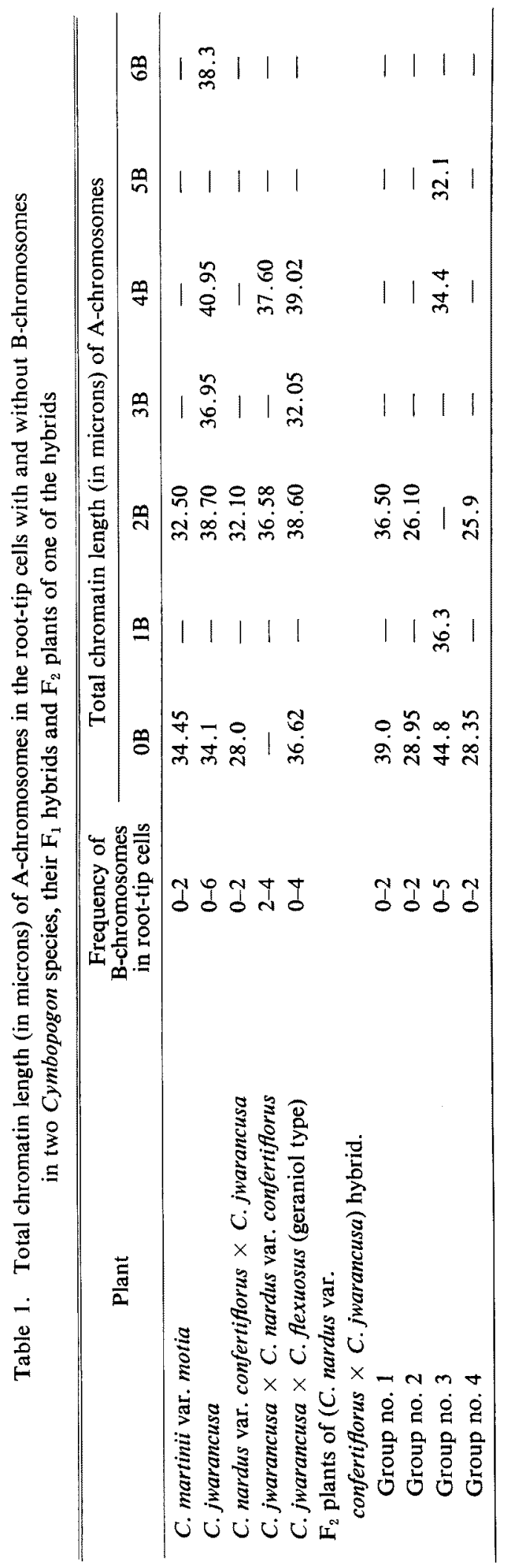




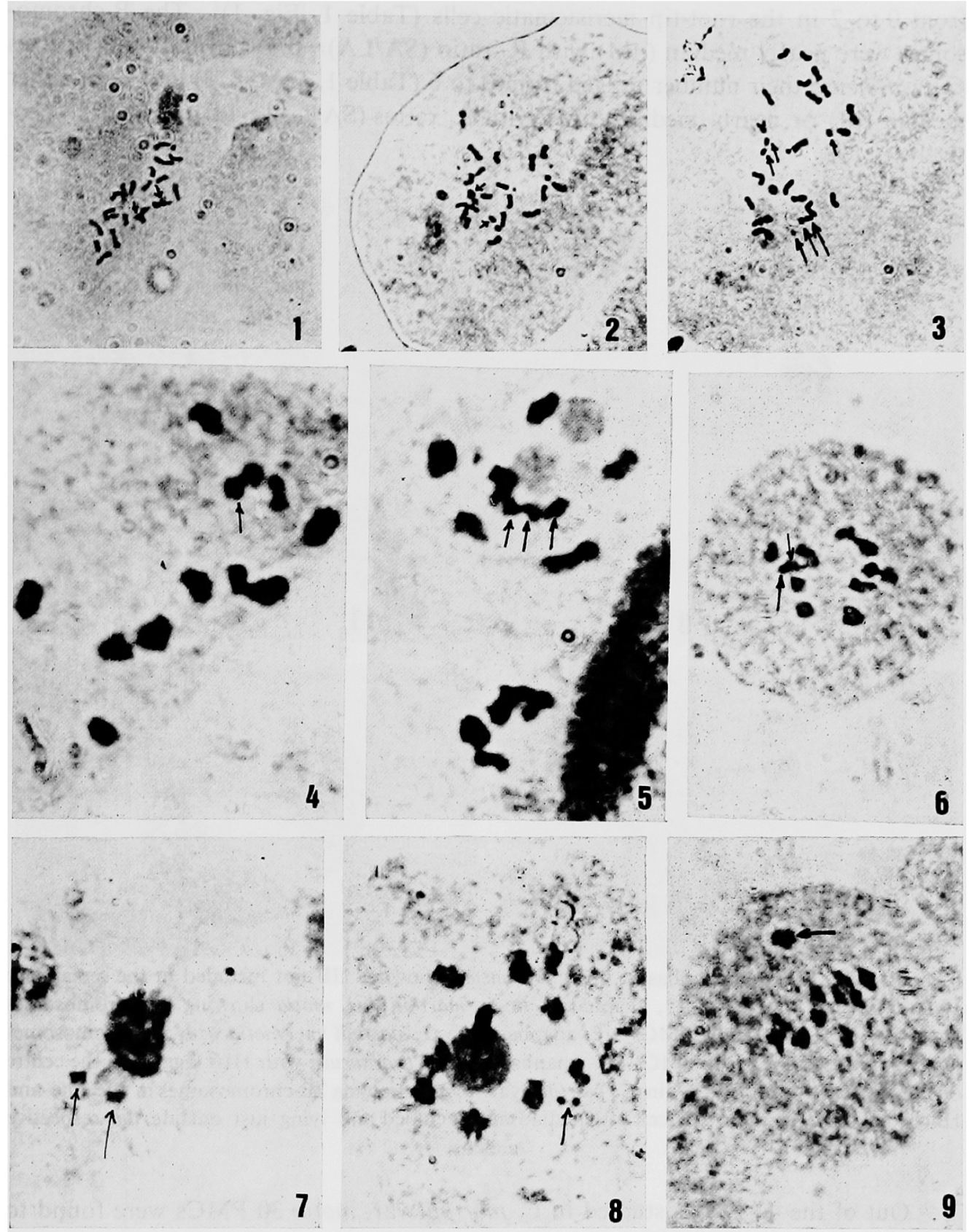

Figs. 1-9. 1, root-tip metaphase in C. martinii var. motia with $2 \mathrm{n}=22=20+2 \mathrm{~B}$-chromosomes. 2 , root-tip metaphase in $C$. jwarancusa with $2 \mathrm{n}=22=20+2 \mathrm{~B}$-chromosomes. 3, root-tip metaphase in $C$. jwarancusa with $2 \mathrm{n}=26=20+6 \mathrm{~B}$-chromosomes. 4 , diakinesis in $C$. martinii var. motia with $2 \mathrm{n}=22=10 \mathrm{II}+1 \mathrm{IIB}$. 5, diakinesis in $C$. martinii var. motia with $2 \mathrm{n}=26=10 \mathrm{II}+3 \mathrm{IIB}$. 6, diakinesis in $C$. martnii var. motia with $2 \mathrm{n}=22=10 \mathrm{II}+2 \mathrm{IB}$. 7, late metaphase $\mathrm{I}$ in $C$. martinii var. motia showing 2IB-chromosomes not included in the metaphase equatorial plate of the PMC. 8 , diakinesis in $C$. jwarancusa with $2 \mathrm{n}=22=10 \mathrm{II}+2 \mathrm{IB}$. 9, metaphase $\mathrm{I}$ in $C$. jwarancusa with $2 n=22=10 \mathrm{II}+1 \mathrm{IIB}$. The B-chromosome bivalent is lying outside the equatorial plate of the PMC. 
from 0 to 2 in the root-tip meristematic cells (Table 1, Fig. 1). The B-chromosomes were nearly median (nM) with $\mathrm{R}_{1}$ ratio $(\mathrm{SA} / \mathrm{LA})=0.8$. In the other species C. jwarancusa their number ranged from 0 to 6 (Table 1, Figs. 2,3) and were either median $(\mathrm{M})$ or nearly median $(\mathrm{nM})$ with $\mathrm{R}_{1}$ ratios $(\mathrm{SA} / \mathrm{LA})=1.0$ and 0.72 , respectively.



Figs. 10-14. 10, late metaphase I in C. jwarancusa showing 1IB not included in the metaphase equatorial plate of PMC. 11, anaphase $\mathrm{I}$ in C. martinii var. motia showing 2B-chromosomes lagging in the centre of the PMC. 12, anaphase I in C. martinii var. motia with 5B-chromosomes lagging in the centre of the PMC. 13, anaphase I in C. jwarancusa with 1IIB lagging in the centre of the PMC. 14, telophase I in C. martinii var. motia showing 2B-chromosomes in the one and $1 \mathrm{~B}$-chromosome in the other cell of the diad, not included and lying just outside the respective nucleus.

Out of the 40 PMCs studied in C. martinii var. motia 30 PMCs were found to have B-chromosomes at diakinesis and metaphase I stages. Their frequency ranged from 0 to 6 with an average of $1.75 \mathrm{~B}$-chromosomes/PMC (Table 2). In $C$. jwarancusa $21 \mathrm{PMCs}$ out of the $40 \mathrm{PMCs}$ investigated contained B-chromosomes. Their number ranged from 0 to 3 with an average of $1.07 \mathrm{~B}$-chromosomes/PMC. In both the species the B-chromosomes when present in even numbers mostly formed bivalents but when present singly they remained as univalents (Figs. 4-6, 8, 9). Neither any multivalent formation nor any bivalent formation with Achromosomes was observed. The average association of B-chromosomes per PMC was $0.25 \mathrm{I}+0.75 \mathrm{II}$ in $C$. martinii var. motia and $0.73 \mathrm{I}+0.17 \mathrm{II}$ in $C$. 


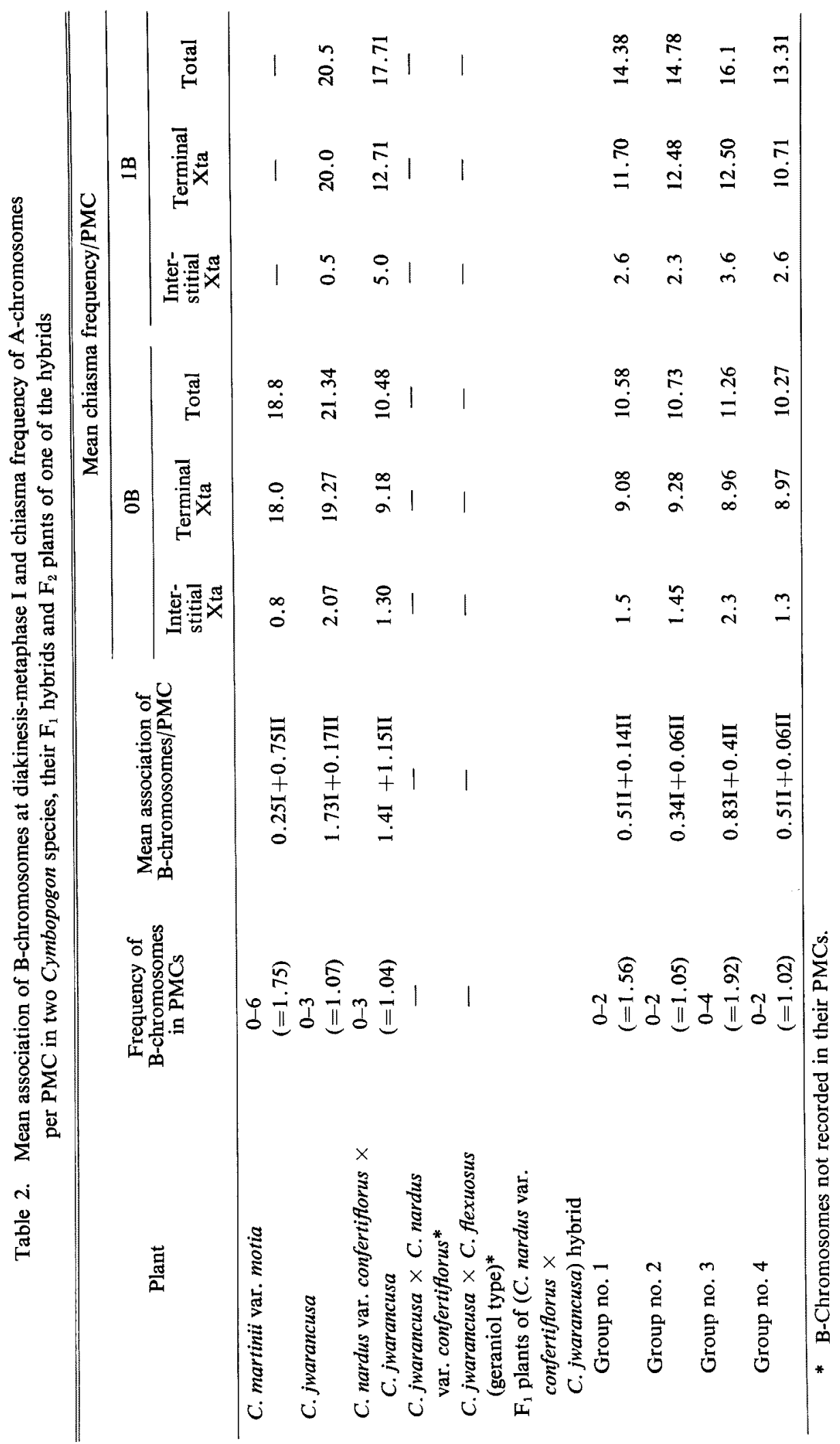







jwarancusa. They were mostly seen lying outside the equatorial plate of late metaphase I (Figs. 7, 10), possibly due to their slow movement to orient themselves on the equatorial plate compared to A-chromosomes. Only 4 out of 35 PMCs, studied in C. martinii var. motia and 6 out of 30 PMCs studied in C. jwarancusa showed the normal segregation of the B-chromosomes to the two poles at anaphase $\mathrm{I}$. The remaining PMCs in both species showed either early movement of B-chromosomes or they lagged and were later included in one of the cells of the diad (Figs. 11-14).

The B-chromosomes divided precociously during second meiotic division and failed to congress at the equatorial plate and their movement to the two poles was synchronised with the movement of the A-chromosomes. Sometimes they failed to get included in the nucleus and are observed as deeply staining bodies outside the nucleus (Fig. 14). Their number varied from 0 to 4 in the pollen grains.

Effect of B-chromosomes on the chiasma frequency of A-chromosomes

There is a marked increase in chiasma frequency of A-chromosomes in $C$. martinii var. motia (both interstitial and terminal) in presence of 2 or more Bchromosomes (Table 2). The maximum increase in interstitial chiasma frequency in A-chromosomes has been recorded in PMCs with 4 B-chromosomes followed by those with 6 B-chromosomes, and least in PMCs with 2 B-chromosomes. In case of $C$. jwarancusa decrease in total chiasma frequency and interstitial chiasma frequency per PMC in presence of $1 \mathrm{~B}$-chromosome was observed. The frequency of terminal chiasma increased slightly in presence of $2 \mathrm{~B}$-chromosomes. However, the presence of $3 \mathrm{~B}$-chromosomes increased the interstitial as well as total chiasma frequency/PMC in this species (Table 2).

Effect of B-chromosomes on the total chromatin length of A-chromosomes

The presence of B-chromosomes also affected the total chromatin length of A-chromosomes as observed in the root-tip cells (Table 1). The presence of $2 \mathrm{~B}$ chromosomes resulted in slight decrease in the total chromatin length of the Achromosomes of the complement in case of $C$. martinii var. motia and increase in chromatin length of $C$. jwarancusa upto the presence of $4 \mathrm{~B}$-chromosomes. Further increase in the number of B-chromosomes in C. jwarancusa resulted in decrease in the chromatin length (Table 1) of A-chromosomes.

\section{Study of the B-chromosomes in three $F_{1}$ hybrids}

The hybridisation involved three Cymbopogon species viz. $C$. jwarancusa $(2 \mathrm{n}=20), C$. nardus var. confertiflorus $(2 \mathrm{n}=20)$ and $C$. flexuosus (geraniol chemotype, $2 \mathrm{n}=20$ ). The other B-chromosomes carrying species $C$. martinii var. motia did not cross with any of the Cymbopogon species and varieties included in the present investigation. The following three $F_{1}$ hybrids carrying $B$-chromosomes were recorded:

1. C. nardus var. confertiflorus $\times$ C. jwarancusa.

2. C. jwarancusa $\times C$. nardus var. confertiflorus.

3. C. jwarancusa $\times$ C. flexuosus (geraniol chemotype).

Out of these, only hybrid no. 1 (C. nardus var. confertiflorus $\times$ C. jwarancusa) carried B-chromosomes both in its root-tip meristem as well as PMCs. In hybrid nos. 2 and 3 the B-chromosomes were present only in their root-tip cells and were 
absent in the PMCs (Tables 1, 2).

There was a general increase in the total chromatin length of A-chromosomes complement with the increase in the number of B-chromosomes in the root-tip cells of all the three $F_{1}$ hybrids (Table 1). But in hybrid no. 3 the presence of 3 Bchromosomes resulted in the decrease in total chromatin length of the A-chromosomes (Table 1).

The behaviour of B-chromosomes in PMCs could be studied only in the hybrid no. 1 as the B-chromosomes were absent in the PMCs of other two hybrids. The general behaviour of the supernumerary chromosomes in the PMCs of this hybrid was similar to that in its pollen parent $C$. jwarancusa. The pollen fertility of the plant was only $16.34 \%$. The presence of B-chromosomes resulted in the proportional increase in the total chiasma frequency of A-chromosomes (Table 1).

3. Study of the B-chromosomes in the $F_{2}$ plants of the $F_{1}$ hybrid, $C$. nardus var. confertiflorus $\times C$. jwarancusa

The $F_{2}$ plants of the hybrid no. 1 were classified into 4 groups on the basis of their morphology and chemical constitution. The above 4 groups of $F_{2}$ plants possessed varying number of B-chromosomes in their root-tip cells as well as PMCs (Tables 1,2). The plants belonging to groups 1,2 and 4 had root-tip cells with either $\mathrm{OB}$ or $2 \mathrm{~B}$-chromosomes in addition to the normal A-chromosome complement of $2 n=20$. The total chromatin length of A-chromosomes in presence of 2B-chromosomes in all the above three groups of plants (groups 1, 2 and 4) was less than that of the cells without B-chromosomes (Table 1). However a single plant included in the group no. 3 had root-tip cells with 0B, 1B-, 4B- and 5B-chromosomes. The total chromatin length of A-chromosomes in the root-tip of this plant decreased proportionately with the increase in the number of B-chromosomes and was least in presence of 5B-chromosomes (Table 1). However the behaviour of $\mathrm{B}$-chromosomes in PMCs was similar to that in the original parent plant $(C$. jwarancusa) and $F_{1}$ hybrid no. 1. The pollen fertility in all $F_{2}$ plants was reduced in general and the plants included in group no. 3 showed almost complete pollen sterility.

\section{Discussion}

The present study of B-chromosomes in the two species of the genus cymbopogon i.e. C. martinii var motia and C. jwarancusa shows that the behaviour of these supernumerary chromosomes in the above species is similar to the behaviour of such chromosomes in other grass species. The B-chromosomes in root-tip cells as well as in PMCs has also been reported in Plantago coronopus (Palival and Hyde 1959). . There are many earlier reports in which the B-chromosomes are stated to be present only in the germline or only in somatic tissue (Darlington and Thomas 1941; Müntzing 1946 a, b, Sudharshan and Jagadish Chandra 1980).

In the present study the B-chromosomes were found to be smaller than the smallest chromosome of the normal complement, the feature which has also been observed earlier in several plants (Raghuvanshi and Joshi 1964, Jones 1975, 
Raghuvanshi and Upreti 1977, Gupta and Gupta 1977). The presence of Bchromosomes in above two Cymbopogon species does not show any effect on the morphology of the plants. However, the B-chromosomes have been observed to effect the chiasma frequency and genetic recombination of the A-chromosomes (Table 2). The increase in number of B-chromosomes upto 4B-chromosomes per $\mathrm{PMC}$ results in the increase in chiasma frequency in A-chromosomes. But further increase in their number does not result in corresponding increase in the chiasma frequency of A-chromosomes (Table 2). Such an effect has also been reported in other plants (Shah 1967, Simchen et al. 1971, Zarchi et al. 1972, 1974, Müntzing 1974, Rees 1974, Jones 1975, Kaul and Wakhlu 1976, Brown and Jones 1976, Raghuvanshi and Singh 1977).

In the case of $C$. jwarancusa there was an increase in the total chromatin length of A-chromosomes with the increase in the number of B-chromosomes whereas in the case of $C$. martinii var. motia increase in their number resulted in the decrease in total chromatin length of A-chromosomes. The present study confirms the earlier finding of Grun (1959), Bosemark (1956), and Frost (1954) that the effect of B-chromosomes on chiasma frequency and total chromatin length differs with different genomes.

In the interspecific hybrids the B-chromosomes were restricted to the root-tip cells of 2 such hybrids (nos. 2 and 3), while in one of the hybrids (no. 1) they were present in root-tip cells as well as PMCs. Their absence from the PMCs of the two hybrids may be due to their elimination prior to sporogensis because of their having weak centromeres. Bianchi et al. (1961) and Carlson (1970) attributed the losses of B-chromosomes to the non-disjuction due to the presence of heterochromatin. The amount of heterochromatin present in a B-chromosome is reported to play a significant role in the non-disjunction and increase in the number of these chromosomes (Roman 1949, Müntzing 1946b, 1954, Bosemark 1957, Lima-deFaria 1962).

Various postulations have been made to explain the effect of B-chromosomes on the chiasma frequency of A-chromosomes. Ayonoadu and Rees (1968) and Barlow and Vosa $(1969,1970)$ suggested that the presence of B-chromosomes results in an increase in number of sites of chiasma formation and also results in delay of terminalization of chisama in A-chromosomes. Barlow and Vosa (1970) suggested that the presence of B-chromosomes reduced the negative interference between the sites of chiasma formation and prolong the time of effective pairing in proportional increase in the total chiasma frequency of A-chromosomes. Subha Rao and Pantulu (1978) showed that it is the balance between euchromatin and heterochromatin that decides the effect of B-chromosomes on the chiasma frequency of Achromosomes. However it is possible that the presence of B-chromosomes might be effecting more than one factors influencing the chiasma formation in the Achromosomes.

The effect of B-chromosomes on the total chromatin length and chiasma frequency of A-chromosomes in the $F_{1}$ hybrids is similar to that observed in parental species. But these affects due to the presence of B-chromosomes appear to get modified in the $\mathrm{F}_{2}$ plants raised from the hybrid no. 1 . There is a progressive de- 
crease in the total chromatin length of A-chromosomes with the increase in number of B-chromosomes in root-tip cells which is particularly significant in plants belonging to group no. 3 , where the least chromatin length of $32.1 \mu$ has been recorded in presence of 5B-chromosomes.

Thus the present work clearly shows that the presence of B-chromosomes effects the total chromatin length and the chiasma frequency of A-chromosomes. And this effect is variable and depends on the genome type and the number of Bchromosomes present in the plant. However, these chromosomes do not show any significant change in the morphology or chemical composition of the plants carrying them.

\section{Summary}

The B-chromosomes were detected in two species (C. martinii var. motia and $C$. jwarancusa) out of the 9 species of genus Cymbopogon investigated. The supernumerary chromosomes were found in both the root-tip meristematic cells as well as the PMCs. Investigations with respect to nature and behaviour of the accessary chromosomes were made in the two parental B-chromosomes carrying species, their $F_{1}$ hybrids with other Cymbopogon species and in the $F_{2}$ population raised from one of the partially fertile $F_{1}$ hybrids. The above study clearly shows that the B-chromosomes have a direct effect on the total chromatin length and the chiasma frequency of A-chromosomes. However, no effect on the general morphology or chemical composition of the oil of the plants has been noticed in presence of the accessary chromosomes. The significance of the data on accessary chromosomes is discussed.

\section{Acknowledgements}

The authors are thankful to Dr. C. K. Atal, Director, Regional Research Laboratory, Jammu for providing facilities for the above work.

\section{References}

Ayonoadu, U. and Rees, H., 1968a. The influence of B-chromosomes on chiasma frequencies in Black Mexican sweet corn. Genetica (The Hague) 39: 75-81.

Barlow, P. W. and Vosa, C. G., 1969. The chromosomes of Puschkinia libanotica during meiosis. Chromosoma (Berl.) 27: 436-437.

- and - 1970. The effect of supernumerary chromosomes on meiosis in Puschkinia libanotica (Liliaceae). Chromosoma (Berl.) 30: 344-355.

Bianchi, A., Bellinig, G., Contin, M. and Otta Viano, E. 1961. Nondisjunction in the presence of inter-changes involving B-type chromosomes in maize, and some phenotypical consequences of meaning in maize breeding. Zeitr. Indulet. Abstamm. Vererblehra. 92: 213-232.

Bosemark, N. O. 1956. On accessary chromosomes in Festuca pratensis III. Frequency and geographical distribution of plants with accessary chromosomes. Hereditas 24: 189-210.

- 1957. On accessary chromosomes in Festuca pratensis V. Influence of accessary chromosomes on fertility and vegetative development. Hereditas 43: 211-235. 
Brown, L. M. and Jones, R. N. 1976. B-chromosomes effects at meiosis in Crepis capillaris. Cytologia 41(3, 4): 493-506.

Carlson, W. R. 1970. Non-disjunction and iso-chromosomes formation in the B-chromosomes of maize. Chromosoma (Berl.) 30(3): 356-365.

Darlington, C. D. and Thomas, P. T. 1941. Moribd mitosis and the activity of inert chromosomes in Sorghum. Proc. Roy. Soc. London, B. 130: 127-150.

Frost, S. 1954. The genetic effect of accessary chromosomes in Centaurea scabiosa. Hereditas 40: 529-533.

- 1958. The geographical distribution of accessary chromosomes in Centaurea scabiosa. Hereditas 44: 112-122.

Grun, P. 1959. Variability of accessary chromosomes in native populations of Allium cernuum. Amer. J. Bot. 46: 218-224.

Gupta, R. and Gupta, P. K. 1977. B-chromosomes in five species of Crotalaria L. Cytologia 42(2, 3): 581-585.

Jagdish Chandra, K. S. 1975a. Cytogenetical evolution in some species of Cymbopogon Spreng. In Advancing Frontiers in Cytogenetics, ed. P. Kachroo. Hindustan Publ. Corp., New Delhi, P 368.

Zarchi, Y. 1975b. Recent studies on Cymbopogon Spreng (Aromatic grasses) with special reference to Indian taxa: Cultivation and ecology: A review. J. Plantation Crops. 3(1): 1-5.

Jones, R. N. 1975. B-chromosome systems in flowering plants and animals species. Int. Rev. Cytol.: 40: 1-100.

Kaul, A. K. and Wakhlu, A. K. 1976. B-chromosomes in Aster novaeangliae L. Caryologia 29(4): 369-375.

Lima-de-Faria, A. 1962. Genetic interaction in rye expressed at chromosomes phenotype. Genetics 47: 1455-1462.

Müntzing, A. 1946a. Cytological studies of extra fragment chromosomes in rye III. The mechanism of non-disjunction at the pollen mitosis. Hereditas 32: 97-119.

- 1946b. Different chromosome numbers in root-tips and plloen mother cells in sexual strains of Poa alpina. Hereditas 32: 127-129.

- 1954. Cytogenetics of accessary chromosomes (B-chromosomes). Proc. 9th International Cong. of Genetics. Caryologia 6 (suppl.): 282-301.

- 1974: Accessary chromosomes. Ann. Rev. Genet. 8: 243-266.

Palivol, R. L. and Hyde, B. B. 1959. The association of a single B-chromosome with male sterility in Plantago coronopus. Am. J. Bot. 46: 460-466.

Raghuvanshi, S. S. and Joshi, S. 1964. Trigonella foenum-graeceum B-chromosomes. Curr. Sci. 33(21): 654-655.

- and Singh, D. N. 1977. Extra chromosomes: Genetic activity, inheritance and transmission. The Nucleus, 20(1, 2): 157-160.

- and Upreti, M. 1977. A new category of B-chromosomes in Trigonella foenum-graeceum. Curr. Sci. 46(22): 789-790.

Rees, H. 1974. B-chromosomes. Sci. Prog. Oxf. 61: 535-554.

Roman, H. 1949. Selective fertilisation in maize. Genetics 33: 122.

Shah, S. S. 1967. Chiasma frequency in euchromatic and heterochromatic chromosomes (Dactylis glomerata sp. lusitanica). Heredity 22: 443.

Simchen, G., Zarchi, Y. and Hillel, J. 1971. Supernumerary chromosomes in the second outbreeding species of wheat group. Chromosoma (Berl.) 33: 63-69.

Subha Rao, M. V. and Pantulu, J. V. 1978. The effects of derived B-chromosomes on meiosis in pearl millet Pennisetum typhoides. Chromosoma (Betl.) 69: 121-130.

Sudharshan, M. R. and Jagadish Chandra, K. S. 1980. The diffuse stage in the meiosis of Cymbopogon caesius. Curr. Sci. 49(7): 286-287.

Verma, V. 1981. Cytogenetical and hybridisation studies in the genus Cymbopogon Spreng. Ph. D. Thesis submitted to University of Jammu, Jammu Tawi 180001.

- and Sobti, S. N. 1982. Karyological studies in the genus Cymbopogon Spreng. I. The Nucleus 25(3): 165-171. 
Zarchi, Y., Hillel, J. and Simchen, G. 1974. Supernumerary chromosomes and chiasma distribution in Triticum speltoides. Heredity 33(2): 173-180.

-, Simchen, G., Hillel, J. and Schaap, T. 1972. Chiasmata and the breeding system in wild population of diploid wheats. Chromosoma (Berl.) 38: 77-94. 